\title{
Panentheism and its neighbors
}

\section{Mikael Stenmark ${ }^{1}$ (D)}

Received: 10 October 2018 / Accepted: 19 October 2018 / Published online: 27 October 2018

(c) The Author(s) 2018

\begin{abstract}
In this paper I suggest that we should identify panentheism on a scale, with deism at one extreme and pantheism at the other. The surprising outcome of the analysis is that many of the things which in the philosophical and theological debate are simply taken for granted as distinguishing panentheism from traditional theism (and vice versa) turn out to be possible extension claims rather than core doctrines of these different conceptions of God. Nevertheless, I maintain that it remains possible to draw a line between them. It is also emphasized that the greatest challenge many panentheists face is to give a convincing argument why we should think that God's power can never be coercive, but must always be persuasive. The good news is that there is nothing in panentheism that requires that we must accept this particular doctrine.
\end{abstract}

Keywords Panentheism $\cdot$ Classical theism $\cdot$ Deism $\cdot$ Pantheism $\cdot$ Process theism

One of the models or conceptions of God that has received most attention recently, among both philosophers and theologians, is panentheism. It has been developed in several different ways and has been contrasted on the one hand with (traditional) theism and on the other with pantheism. But what is panentheism and how, more exactly, should we state the core differences between it and (traditional) theism and, secondly, between it and pantheism? All this is far from clear, but we need to find answers if panentheism is intended to become the golden middle road between these two perceived extremes. The main objective of this essay is to try to answer this question, but I shall also consider how these three conceptions of God should be related to deism, since in the debate deism and (traditional) theism are quite often confused. I shall also try to formulate some of the challenges facing those philosophers and theologians who advocate a panentheistic conception of God.

Panentheists such as Michael W. Brierley and Philip Clayton talk about a "quiet revolution" and the "panentheistic turn" in modern theology, meaning that they are

Mikael Stenmark

mikael.stenmark@teol.uu.se

1 Department of Theology, Uppsala University, Box 511, 75120 Uppsala, Sweden 
turning away from or challenging another understand of God. ${ }^{1}$ It is in this context that "traditional" in my notion of "traditional theism" should be understood. It refers to the traditional conception of God that they reject; the default view to which they wish to propose an alternative. In the "A first approximation to the different models of god" section of the article, I shall suggest a first approximation to minimal versions of panentheism and three of its main rivals. In the "The panentheistic debate" section I shall respond to some of the arguments raised by philosophers and theologians participating in the contemporary debate between panentheists and traditional theists and which seem to challenge my initial typology, and if necessary revise it accordingly.

\section{A first approximation to the different models of god}

I suggest that the most fruitful approach is to identify panentheism on a scale which has deism at one extreme and pantheism at the other. This also allows us to identify paradigmatic cases of each conception of God (or the divine), while allowing that there are grey areas between these views that might be harder to classify appropriately. I shall focus my attention on the borderline between panentheism and traditional theism and on some of the implications their core claims are taken to have.

I shall assume that these conceptions of the divine are concerned with who God is and with God's relation to the world-including God's relationship to human beings. This has certain implications for how we understand pantheism. That is to say, I shall exclude from the discussion at this point all those pantheists, like for instance Albert Einstein, who reject any notion of a personal or person-like God. In other words, I will take "theism" in pantheism literally, assuming that, in that sense, one cannot be a pantheist and yet deny the existence of God or at least of something similar to God, or God-like. So, I shall assume that minimal personal theism is something that these conceptions of God have in common:

(MPT) God is conscious or mind-like, or personal or person-like, or has prop-

erties at least similar to those of a person.

Minimal personal theists assume that God has certain important qualities that we associate with ourselves as persons, or are at least similar to those qualities. (Extended versions of personal theism assume that God is a person, or even a perfect person.) The proposition (MPT) might still be too strong to capture adequately the "theism" in "pantheism," but it will suffice in this context, because my focus will be on the similarities and dissimilarities between panentheism and traditional theism. I shall further distinguish between what I take to be core claims and extension claims of these conceptions of God. As we shall see, there is debate among philosophers and theologians about whether some of these assertions are to be considered core

\footnotetext{
1 Michael W. Brierley, "Naming a Quiet Revolution: The Panentheistic Turn in Modern Theology," eds. Philip Clayton and Arthur Peacocke, In Whom We Live and Move and Have Our Being, Grand Rapids, Mich.: Eerdmans, 2004.
} 
or extension claims, and I shall give my reasons for classifying a claim in one way rather than the other.

\section{Deism}

I suggest that deism contains minimal personal theism (MPT) and at least the following core claims:

(1) God is ontologically distinct from the world;

(2) God is the creator of the world, so the world depends on God for its origin;

(3) God could exist without this world or without any other world, so God in no way depends on the world for God's own existence;

(4) Once God has created the world, it does not depend on God for its continuing existence.

Deists believe that God exists independently of the world. God is $a$ se, that is, is wholly ontologically independent of all else. God could possibly be affected by the world or what is going in in the world (this could be a deistic extension claim, as could its denial), but God's existence does not in any way depend on the existence or fate of the world. Nevertheless, there is a world, and that means that God is the creator of it. The world would not have come into existence without God's creative activity. Deists believe that God created the world, but thereafter God has exercised no provisional care or control over what goes on in that world. The continuing existence of created things requires no activity by God beyond that of having created them in the first place. God respects the full autonomy of the world and its inhabitants and has accordingly created it so. I shall come back to what we might name propositions (1), (2) and (3) in my discussion of traditional theism, but I suggest we call (4) the doctrine of world self-sufficiency, since it entails that God has guaranteed the full autonomy or self-existence of the world and its inhabitants. God, having created them, leaves them and their environment alone, so that they can exist and survive left to their own devices, on their own steam, as one might say.

\section{Traditional theism}

The second model of God, traditional theism, contains minimal personal theism (MPT), claims (1), (2), (3) and at least the following further core claim:

(5) The continuing existence of the world depends on God's ongoing creative activity.

Both deists and traditional theists maintain that God and the world are ontologically distinct (claim 1); they are neither ontologically the same nor in any way identical or overlapping. Deists and traditional theists, furthermore, emphasize that God could exist without this world or without any other world (claim 3). These two ideas will be of utmost importance when we try to distinguish between panentheism and traditional theism, so I suggest that we name (1) the doctrine of ontological distinction, 
and (3) the doctrine of asymmetrical ontological dependence. Deism and traditional theism also share the doctrine of creation, which concerns the origin of things; thereby both embrace (2).

It is in maintaining that the continuing existence of the world depends on God's ongoing creative activity that traditional theists proclaim one of the features distinguishing their understanding of divine action from that of the deists. This is what I have tried to capture in (5). Thomas V. Morris writes:

God does not just bring things into existence and then take a hands-off approach to them. This is the error known as deism. God continually supports things in existence, moment to moment, throughout the entirety of their careers on the stage of reality. Divine conservation is thought to be so absolute a requirement for existence that, if God were to withdraw his support for our contingent universe for even an instant, it would all cease to be. ${ }^{2}$

So, whereas the doctrine of creation concerns the origin of things, the doctrine of conservation concerns God's active role in the continued existence of created things. Claim (5) is meant to capture the doctrine of conservation, which entails a rejection of the doctrine of world self-sufficiency as expressed in (4). God is conceived by traditional theists to be both the creator and sustainer of all that exists, and not as deists believe simply the creator. We could perhaps say that the transcendence of God is expressed though the doctrine of ontological distinction and the doctrine of asymmetrical ontological dependence and that the immanence of God is captured in the doctrine of conservation.

\section{Panentheism}

On a first approximation, panentheism contains minimal personal theism (MPT), (2), (5), and at least the following core claims:

(6) God ontologically includes the world, that is, the world is a part of God;

(7) God depends on the world (or the creation of another world) for God's own existence.

Claims (6) and (7) attempt to explicate the "pan" and the "en" in panentheism. Panentheists, like deists and traditional theists, believe in a personal or personal-like God, but reject the idea that God is ontologically distinct from the world. Rather, the world is God's body, through which God lives his or her life, as we live our lives through our bodies. God, like a human person, is physically embodied in a body and is growing older through time, and changes as the world changes. Since the world constitutes a part of God, God is ontologically affected by changes in the world. God is within, but not totally confined by, the temporal order and nothing comes into being except through God. But God nevertheless needs a body (a world) for God's existence. God could not exist without that part of Godself. There is thus an

2 Thomas V. Morris, Our Idea of God, Notre Dame, Ind.: University of Notre Dame Press, 1991, 155. 
ontological inclusion between God and the world, but it is still appropriate to talk about the world as God's creation since nothing comes into being except through God. However, on a panentheistic account, creation cannot be ex nihilo (out of nothing) as many traditional theists believe it can, because God always needs a world to exist. Panentheists do not deny the contingent nature of the world. The essence of God is different from that of the world because God is infinite, and the world is finite. God is everlasting; the world is temporal.

Since panentheists affirm that the world is a part of God but not identical with God, they reject the doctrine of ontological distinction and embrace instead what I shall call the doctrine of ontological inclusion. This claim supports the idea that God's relation to the world must be more symmetrical than traditional theists think it is. Panentheists do not deny that the continuing existence of the world depends on God's creative activity. This is the doctrine of conservation, as expressed in (5). But they believe that God could not exist without the world or without a world, just like we-assuming that dualism is false-cannot exist without our body or a new resurrected body (as Christians might say), while still being more than our body. Thus, I suggest that panentheism essentially contains the doctrine of symmetrical ontological dependence, that is, the relation of ontological reliance goes both ways. Not just from God to the world, which the doctrine of asymmetrical dependence says, but from the world to God: not only no God, no world; but also no world no God. We could perhaps say that panentheists do not really need the doctrine of conservation because its content is fully covered by the doctrine of symmetrical dependence.

However, and as Philip Clayton points out, we need to consider that the human mind-body interaction is a "panentheistic analogy." So, although we could and should model God's relation to the world on how the human consciousness or mind is related to our body, God's relation to the world is still different in important ways. ${ }^{3}$ One obvious difference is of course that our mind or consciousness is contained in but different from our physical body, whereas God's mind (or at least an essential part of it) goes beyond or is "outside," ontologically speaking, of God's body, so that God is not exhausted by the world. God contains the world, yet is also more than the world. In other words, for panentheists, the transcendence of God is expressed through the doctrine of ontological inclusion and the immanence of God is captured in the doctrine of ontological symmetrical dependence. Niels Henrik Gregersen worries that God in the panentheistic analogy might appear as an emergent reality arising out of natural processes rather than the other way round, ${ }^{4}$ and this on a panentheistic understanding would be a false implication to draw from the analogy. Moreover, the idea is not that God responds to a portion of the world as we do, insofar as we have direct access merely to the segment of the world which constitutes our particular bodies. Rather, the entire world functions for God the way our bodies function of us; thus giving God immediate or privileged access to everything in the world.

\footnotetext{
3 Philip Clayton, God and Contemporary Science, Grand Rapids, Mich.: Eerdmans, 1997, 233.

4 Niels Henrik Gregersen, "Three Varieties of Panentheism," eds. Philip Clayton and Arthur Peacocke, In Whom We Live and Move and Have Our Being, Grand Rapids, Mich.: Eerdmans, 2004, 20.
} 


\section{Pantheism}

Now a few words about the last member on our conceptual scale, namely, pantheism. It, I suggest, contains minimal personal theism (MPT), (7), and at least the following core claim:

(8) God is ontological identical with the world, so that all things in the world are parts or aspects of God, and there is no part or aspect of God which is not a part or aspect of the world.

Pantheists, like panentheists, believe that God is all there is, but they also maintain that the world is all there is, which is something the latter group deny. There exists nothing that is outside of God and nothing that is outside of the world. Thus, (8) expresses what we can call the doctrine of ontological identity. It should be contrasted with the panentheistic doctrine of ontological inclusion and of course with the deistic and traditional theistic doctrine of ontological distinction. We could either say that pantheists embrace the doctrine of ontological symmetrical dependence (that is, the relation of ontological reliance goes from God to the world and from the world to God) or that it is included in, perhaps even entailed by, the doctrine of ontological identity. In fact, the God-world and world-God ontological interdependence appears even stronger than in panentheism. In the latter, God needs a world, though not necessarily this world. God could create another body to inhabit. The pantheistic God, on the other hand, has only this world: a world that God could re-create or re-shuffle in creative ways, but one which would nonetheless still be this world.

The idea that the relation between God and the world is analogous to the relation between our mind and our body seems even more apt to describe the pantheistic conception of God than the panentheistic one, since it mirrors this relation even more closely. Just like our mind is contained in but is different from our physical body so God's mind is contained in but different from the physical universe. In the pantheistic analogy, this analogy does not at this point break down since pantheists are not, in contrast to panentheists, committed to the idea that God's soul or mind goes beyond or is ontologically speaking not exhausted by the world. On a (personal) pantheistic conception of God, one could say that God is the soul of the world as a whole or the universal spirit present everywhere in the world but not beyond it. God is not a partially embodied deity (as in panentheism), but a totally embodied deity.

In this section, we have established a first approximation of the core differences between four models of God. Our focus is primarily on what distinguishes panentheism from traditional theism. My answer is this: whereas the former contains the doctrine of ontological inclusion and the doctrine of symmetrical ontological dependence, the latter includes the doctrine of ontological distinction and the doctrine of asymmetrical ontological dependence. Both however comprise the doctrine of creation and perhaps the doctrine of conservation, unless the panentheistic doctrine of symmetrical dependence replaces it. Hence, we can immediately see that it is misguided to maintain, as John Culp does, that: "Traditional theistic systems emphasize the difference between God and the world while panentheism stresses God's active 
presence in the world." ${ }^{5}$ Both (in contrast to deists) stress the active presence of God in the world, but in different ways. The essential difference is rather that traditional theists think that God is (ontologically) distinct from the world and does not depend on it for God's own existence, whereas panentheists believe that God (ontologically) includes the world and therefore depends on the world for God's own existence.

Let us now turn our attention from this explication of minimal forms of deism, traditional theism, panentheism and pantheism to the debate between panentheists and traditional theists in contemporary theology, in the science-religion dialogue and in philosophy of religion-what I call the "panentheistic debate"-and try to determine what modifications or additions need to be made. One obvious addition has to do with how to conceive of God's goodness, power and knowledge within the framework of these models of God.

\section{The panentheistic debate}

What kinds of objection might philosophers, theologians or scientists, participating in the debate between panentheists and traditional theists in contemporary academia, have against this minimal construal of these models of God? What modifications of these core claims or doctrines would such an inquiry demand, or what additions to them would it be necessary to make? These are the issues I now want to address. We shall of course not be able to go through them all, but let me at least respond to some which I would consider of importance or are frequently raised in the panentheistic debate.

\section{The doctrine of impassibility}

Gregersen maintains that "the idea of bilateral relations between God and the world may ... be said to be distinctive for panentheism." 6 The panentheistic God will not be unaffected by the fates and fortunes of the world. He takes Thomas Aquinas as his key example of a traditional theist and writes that: "The real difference, according to Thomas, is that the natures and activities of the creatures do not have a real feedback effect on God. There is, in other words, no return from the world into God. ... The world is utterly dependent on God for its existence, while the world cannot really affect the being or mind of God (Summa Theologiae 1.28.a.1)."7 This is the doctrine of (divine) impassibility, that is:

(9) God is incapable of emotions, in particular is incapable of feeling any sorrow or suffering as a result of the afflictions of God's creatures.

\footnotetext{
5 John Culp, "Panentheism," Stanford Encyclopedia of Philosophy (Winter 2016 edition), ed. Edward N. Zalta, URL=https://plato.stanford.edu/entries/panentheism/.

6 Gregersen, "Three Varieties of Panentheism," 20.

7 Gregersen, "Three Varieties of Panentheism," 24.
} 
Now it is true that Aquinas is a traditional theist and that many traditional theists hold similar views. But so is Nicholas Wolterstorff, and he embraces minimal traditional theism but rejects the doctrine of impassibility. He writes: "If Aquinas is right in his argument-and I think he is - that aseity implies simplicity, that simplicity implies immutability, and that immutability implies eternity and impassibility, then giving up eternity and impassibility [which is Wolterstorff's own view] implies giving up immutability, simplicity and aseity." 8

What we must pay attention to is that there are at least three main schools of traditional theism: classical theism, neo-classical theism and open theism. Beyond the core claims of minimal traditional theism, classical theists maintain that God is timeless, immutable, simple, impassible, perfectly good or omnibenevolent, omniscient, omnipotent and omnipresent. Neo-classical theists, on the other hand, reject the idea that God is timeless, immutable, simple and impassible, but embrace that God is perfectly good or omnibenevolent, omniscient, omnipotent and omnipresent. Linda Zagzebski even thinks that it is possible that God is maximally empathetic, thus suggesting that another of God's attributes is omnisubjectivity. ${ }^{9}$ Open theists agree with most of the neo-classical doctrines of God, but perhaps the most significant differences are that they think God's knowledge is much more limited, and since God cannot control voluntary human choice, God has given up total control over much of what occurs on earth.

How exactly we might draw the lines between these schools of traditional theism is not essential for us to address in this context. The important point is to see that the doctrine of impassibility is an extension claim of traditional theism, rather than a core claim. It provides one way of extending the minimal version of the model I have explicated; another extension would be to posit that God could have emotions and might even be maximally empathetic. There is nothing within minimal traditional theism that requires or entails one or the other of these extension claims. So, as far as I can see, the bilateral relation that necessarily distinguishes panentheism from traditional theism is the purely ontological one. Traditional theists could, but need not, affirm that the natures and activities of creatures do have real feedback effect on God. It is true that, on such a model of God, the world cannot really affect the existence of God (the doctrine of ontological asymmetrical dependence) but it could influence the affective and cognitive states of God. The idea of bilateral relations between God and the world, at least of the kinds that Gregersen identifies, cannot be said to be distinctive for panentheism.

On the other hand, and on this point Gregersen is quite correct, the affirmation that the natures and activities of creatures do have real feedback effect on God is central to panentheism. For panentheists, the natures and acts of creatures do after all constitute a part of God, so a core claim of panentheism is that God could be moved by suffering in the world:

\footnotetext{
${ }^{8}$ Nicholas Wolterstorff, Inquiring about God (edited by Terence Cuneo), Cambridge: Cambridge University Press, 2010, 14.

${ }^{9}$ Linda Zagzebski, "Omnisubjectivity," ed. J. L. Kvanvig, Oxford Studies in Philosophy of Religion, Vol. 1, Oxford: Oxford University Press, 2008, 231-247.
} 
(10) God is capable of emotions, in particular is capable of feeling sorrow or suffering as a result of the afflictions of God's creatures.

Minimal panentheism should be extended so that it also includes (10), that is, it should include what we can call the doctrine of (divine) sensibility.

\section{The doctrine of divine power}

Let us now turn to the discussion of divine power in the panentheistic debate. Traditional theism holds that God created the world and sustains it at each moment of its existence. This entails that God has immense power on an almost inconceivable scale. God is therefore said to be "almighty," "all-powerful" or "omnipotent," or at the very least God is as powerful as one must be to create the world and sustain its continued existence. Traditional theists disagree on how to explicate the powers necessary to create the world as well as everything else that God can and will do in the world once it is created. Since panentheists also accept the doctrine of creation and have a suitable replacement to the doctrine of conservation in the doctrine of symmetrical ontological dependence, it seems that both models of God must accept the doctrine of (immense) divine power, at least in some minimal form:

(11a) God is at least as powerful as one must be to create the world and sustain its continued existence.

Or we can formulate the doctrine in a more panentheistic terminology:

(11b) God is at least as powerful as one must be to create the world (and if or when necessary replace it with another world) and to sustain the existence of the world, that is, of God's own body.

If something along the lines of (11a) or (11b) is true, then God would have what I shall call the property of being "immensely powerful." Panentheists like Clayton and Knapp agree, as they write: "This mindlike reality [or God] must be inconceivably more powerful than any we encounter in our mundane experiences; it isn't just one mind among many but the source of all other minds." ${ }^{10}$ This discussion of divine power might sound as though God possesses absolute power or brute force, and could entail a glorification of power that might have seriously negative consequences for the possibility for a consistent traditional theist or panentheist to promote a fair and just society. ${ }^{11}$ However, I think that we should resist such terminology and can on good grounds reject such a criticism because both traditional theists and panentheists think that:

(12) God is perfectly good, compassionate and loving.

\footnotetext{
${ }^{10}$ Philip Clayton and Steven Knapp, The Predicament of Belief, Oxford: Oxford University Press, 2011, 37.

${ }^{11}$ This kind of objection to divine power can be found in, for instance, Beverley Clack, "Feminist Approaches to Religion," ed. Graham Oppy, The Routledge Handbook of Contemporary Philosophy of Religion, London: Routledge, 2015, 9.
} 
This is one of their core claims. They all embrace the doctrine of divine goodness. If God is perfectly good and loving, this entails that God embodies, as Charles Taliaferro and Chad Meister point out, praiseworthy powers-God lacks for instance the power to do evil. $^{12}$

A power that the traditional theistic God has, which the panentheistic God lacks, is the power to create ex nihilo (from nothing), the power to bring into existence things which are brought into being not by re-creating previously existing things. There is, so to say, no need for such a form of divine power within panentheism because God already has a body, or the world is already a part of God. Panentheists could be agnostic about God's power to create another kind of world than the sort of world we live in, one which is not a part of God and thus, it seems, must be created ex nihilo. Or perhaps that is not, after all, quite right, because given that panentheists think that this world is contingent and temporal, it seems as if God's new body that will replace this one, once this one has come to the end of the road, needs to be created ex nihilo. More needs to be said on this issue, but I will leave that for another time.

Let us now come to that part of the discussion of divine power in the panentheistic debate that is, according to many panentheists, absolutely crucial; but which, I must admit, I find hard to grasp and even counterintuitive. They assume that at the core of panentheism is the idea that God's power can never be coercive but must always be persuasive. Let us call this claim the doctrine of pure (divine) persuasive power. God does not have the power to unilaterally impose God's will on the world. God is not able to compel human beings or any other things or processes in the world to comply with the divine will. Rather God can, in supreme ways, attract them or "lure" them, and in such a way they (to the degree they are able, given their specific nature) voluntarily comply with God's intentions. Traditional theists, on the other hand, believe that it is through powers which are coercive that God created the world, sustains it as a whole and sometimes chooses to interact with it. God unilaterally forces things to continue to exist, compels natural laws to keep their regularity and could, according to some such theists, force people to do God's will or temporarily alter the laws of nature to perform miracles, such as raising Jesus from the dead or giving the Qur' an to Mohammad. Traditional theists do not deny that God exercises persuasive power and some of them, such as Meister and Taliaferro, even think that the way God generally operates is by exercising persuasive, rather than coercive, power over persons and things. ${ }^{13}$

An addition to (11b) seems, then, to be called for, so that we can distinguish a panentheistic conception of divine power from a traditional theistic one. God is at least as powerful as one must be to create the world (and if or when necessary replace it with another world) and to sustain the existence of the world, that is, of God's own body, but:

\footnotetext{
${ }^{12}$ Charles Taliaferro and Chad Meister, Contemporary Philosophical Theology, London: Routledge, 2016, 109.

${ }^{13}$ Taliaferro and Meister, Contemporary Philosophical Theology, 115.
} 
(13) God's power is and indeed must always be persuasive, and, consequently, can never be coercive.

The idea is that we have to add (13) to the core claims of minimal panentheism. What distinguishes panentheism from traditional theism is not merely the doctrines of ontological inclusion (6) and of the symmetrical ontological dependence (7), but also the doctrine of pure persuasive power. God could influence but not determine any event in the world.

I think that (13) is a problematic position to take and I will come back to this issue in a moment, but let me first raise this question: Why could traditional theists not, if that is the assumption, also embrace the doctrine of pure persuasive power? Why could not both panentheists and traditional theists accept (13)? After all, as we have seen, traditional theists such as Taliaferro and Meister think that the way God generally operates is by exercising persuasive rather than coercive power over persons and things. From this standpoint, it seems like a small step to hold (13) instead. One could perhaps argue that (13) should be embraced because coercive power is not a praiseworthy power, and God only possesses praiseworthy powers. But maybe it is the idea of creation ex nihilo that makes it impossible for traditional theists to accept (13)? In creation ex nihilo, there is nothing there which God could use God's persuasive powers upon, so this form of creation necessarily requires the exercise of coercive power. Notice though that I have not explicitly said that the doctrine of creation ex nihilo is a core claim of traditional theism. It could be implicit in the doctrine of divine power, but so could its denial.

However, let us return to panentheism. At first sight, the idea that God's power can never be coercive but must always be persuasive is truly baffling. We, it seems, know full well the difference between these forms of power, and we simply take it for granted that human beings can exercise both. I can stop the young girl with headphones, next to me, from crossing the street. I simply grab her and hold her back because she fails to see and hear the car speeding in our direction. I could, when they were young, detain my children from going out at night by using my coercive powers. Although I typically tried to convince them, using my persuasive powers, that it would be a good thing for them to go to bed since they must go to school the next morning. We can force the river, by using our coercive power, to take another direction, and we can cut down trees and build houses out of them instead. We can unilaterally change things, whereas God presumably cannot. However, that would mean that we have, to a significant extent, greater powers than the creator of the world; and this must surely be a deeply counterintuitive position to hold.

As far as I can see, panentheists could respond to this objection in five different ways. They could reply by arguing that it is true that it seems like we have coercive power, but that this is just the way it appears to us: just like the earth appears to be stationary, while it is really rotating. Not only God, but no creature in heaven or on earth, has coercive power. Related to this response is the one that says that these notions have a different meaning within panentheism than they have in ordinary language or when traditional theists use them. (We would then need to know what that meaning is and, given that special meaning, also whether traditional theism would entail a rejection or acceptance of these particular notions of coercive and 
persuasive power.) Alternatively, panentheists could argue that although we have coercive power, God lacks coercive power because it is not a praiseworthy power and God has only praiseworthy powers. The fourth option would be to argue that God does not need coercive power because God's persuasive power, in contrast to ours, is maximally perfect. God is like the perfect parent who never needs to use coercive power on his or her children. A last possibility would be maintain that acting coercively is a pseudo-task of the sort that George Mavrodes identifies in "Some Puzzles Concerning Omnipotence," so God's inability to carry out these pseudotasks (such as creating a stone too heavy for God to lift) is undamaging to God's omnipotence. $^{14}$

Now, a perhaps more radical resolution would be to actually accept the objection but then to argue that the doctrine of pure persuasive power, despite its great popularity among panentheists, is not a core but an extension claim. Panentheists wishing to follow this line would reject (13) and perhaps maintain that God generally operates by exercising persuasive rather than coercive power over persons and things. Notice also that the way that Donald Viney formulates the panentheistic understanding of power opens up this possibility. He says that the core idea is merely that "God acts by persuasion rather than by coercion." $" 15$ This, as I have pointed out, is too weak on its own to distinguish panentheism from traditional theism, but it might suggest a way out of these problems for panentheists. Such an interpretation would also fit my overall conclusion so far, namely, that at least there is nothing in the core claims of minimal panentheism (as I have explicated them so far) that requires panentheists to embrace the doctrine of pure persuasive power.

In fact, Clayton and Knapp, in their discussion of the problem of evil, exemplify that this is a live option, although one seldom embraced by panentheists. They write:

Why can't God at least sometimes override the regularities of nature when doing so is needed to prevent innocent suffering? We have answered this question in two ways: first, by showing why the development of rational and autonomous agents requires a greater degree of regularity than might initially be obvious; and second, by arguing that occasional divine abrogations of natural law, even if metaphysically possible, turn out to be morally inconsistent with the capacities of a divine agent - not because breaking natural laws is inherently immoral, but because by doing so God would incur a responsibility to intervene in most or all cases of suffering. But this would make it impossible for God to limit the frequency of such interventions and therefore to preserve a universe in which beings like us could evolve. ${ }^{16}$

The panentheistic God, in other words, would not on this account necessarily lack coercive powers but might have a good reason not to use them and instead rely on

\footnotetext{
14 George Mavrodes, “Some Puzzles Concerning Omnipotence," Philosophical Review, 1963 (72): 221223. I am thankful to one of the reviewers for pointing out this fifth possibility.

15 Donald Viney, "Process Theism," Stanford Encyclopedia of Philosophy (Spring 2014 edition), ed. Edward N. Zalta, URL = https://plato.stanford.edu/entries/process-theism/.

16 Clayton and Knapp, The Predicament of Belief, 52.
} 
God's persuasive powers. God, by using these powers, presents to people's consciousness desirable values, but ones which they are free to embrace, pursue, reject or ignore.

Panentheists could still maintain that God's coercive powers are more limited, or even much more limited, than what traditional theists maintain that they are, due to the idea that the world is a part of God or is God's body. This could be a significant difference between these models of God worthy of further exploration. Maybe the panentheistic analogy could be of help at this point. I can (coercively) force my hands to write these letters, even though I would prefer to be out in the sun in Spain using my hands to play paddle tennis. There are, however, things that you or other people could do with my body that I cannot do myself. A medical doctor has the coercive power to remove my appendix if it is infected. In an analogous way, there might be things that a panentheistic God could not do with the world that a traditional theistic God could do with it. God's powers are as great as they can be for a partially embodied deity. God must, it seems, in some ways be restrained by what constitutes God's body, the nature of physical matter. How to develop this idea or similar ones further I leave open for others to pursue. My point is simply that despite the enormous popularity among panentheists of the idea that God's power can never be coercive, but must always be persuasive, it is reasonable to classify this as an extension claim and not a core claim of panentheism.

\section{Process theism}

Maybe this verdict is premature after all, because there might be some other, not yet identified and discussed, core claim of panentheism which entails the doctrine of pure persuasive power. Panentheists are often called process theists because they express their conception of God within an ontology or a metaphysics where processes rather than substances or things are taken to be the central category. Processes are basic and things are derivative, and not the other way around. Maybe it is here that we can find grounds for the idea that God's power must always be persuasive and can never be coercive. If not, it might still be the case that panentheism requires process ontology whereas traditional theism demands substance ontology. We would then need to add another core claim to the minimal versions of these models of God.

From the time of Aristotle, Western metaphysics or ontology has had a marked tendency in favor of substances, things or beings. The default position in contemporary metaphysics is still to see the world as primarily a collection of things, individuals or objects, bearers of properties and which stand in relations to one another, and which might belong to different kinds or ontological categories-although there are plenty of different ways of developing this kind of metaphysics. Let us call a person working within this framework a "traditional metaphysician." So, from this perspective, it would not be strange to take, as Lynne Rudder Baker suggests, "ontology to be a complete inventory of all the individuals, kinds, and properties that must exist 
for reality to be as it is" 17 or to say, with Michael Rea, that, very roughly, "the distinction between attributes and substances is just the distinction between properties (like being blue) and things that have properties."18

I am an individual, but my height, hair, and employment are not. These are properties I have, or which can be attributed to me. These attributes are properties that things or individuals can have, but they are not in themselves things or individuals. Properties, numbers, and relations are called "universals," and they can have instances; so the relations of being "the father of" or "a sister to" can have many instances. Moreover, traditional metaphysicians would describe the Vietnam War, the biological evolution of living things, or the birth of my daughter as events or processes rather than as individuals or things. Processes such as these are real, but they start and end and happen, or take place or occur; whereas things or individuals come into existence and endure, or last or get older. So whatever else individuals, things, or objects might be, they are not assumed to be events or processes. An event is a change in something or a change in the relations that hold between two or more things. If there were no things extant to undergo change, there could be no events. Within this ontology, God-if God is assumed to exist-is understood to be an individual (admittedly of a unique kind) with properties or attributes such as being extremely powerful, being truly loving, and being the creator of everything that exists; whereas many of God's activities could be descripted as processes, such as the creation of the world and the process of sustaining its continued existence.

Process metaphysicians take their starting point rather in the writings of Alfred North Whitehead than in those of Aristotle, and on this matter diverge from the orthodoxy of Western philosophy. Just as with "thing ontology," process ontology can be developed in different ways, but the core idea is that processes rather than things furnish the basic materials of ontology. Processes are basic and things derivative. It is not just the case that many things, perhaps most, are the product of processes (as traditional metaphysicians believe), but that they are processes themselves (which traditional metaphysicians would deny). We could call some processes "things" or "enduring individuals"- the term that process metaphysicians seem to prefer-if we like, but reality at its most fundamental level consists merely of different kinds of processes. Note also that it is not just events like "it getting warmer" or "it snowing" that are processes, that is to say, events with no defined agent; events such as "I am now talking" or "the tree is growing" are processes too. It is also the case that "Mikael Stenmark," the individual who talks, or "the tree," the thing that grows, are best understood in process-properties-relations terms, rather than in thing-properties-relations terms. All that there ultimately are in the world are not things or individuals and their properties and relations, but processes and their properties and relations. The processes instanced by "Mikael Stenmark" or "the tree" are not subjectless, but have a unity and identity that the former kind lack. They are

\footnotetext{
17 Lynne Rudder Baker, Naturalism and the First-Person Perspective, Oxford: Oxford University Press, 2013, xvi.

18 Michael Rea, Metaphysics, London: Routledge, 2014, 38.
} 
what Nicholas Rescher calls "megaprocesses." ${ }^{19}$ In the case of a particular person we could say that she or he is a structured system of processes, containing a variety of integrated and subordinated processes and a coherent and (relatively) stable center of agency.

It is not merely all things and individuals in the world that are processes; so is God-if God exists. (A process metaphysician could of course deny that God exists.) God is not best seen as an individual or substance but as a process, admittedly not an ordinary process, but a process nevertheless. Again, the idea is not merely that God's creative activities such as sustaining the world or responding to prayers are processes, but that Godself is a process. More exactly, God is, given minimal personal theism (MPT), a personal or personal-like megaprocess.

It does not, however, seem obvious that, if panentheists embrace process ontology, such a commitment would have any direct feedback on the issue of whether they also must, or at least preferably would, embrace the doctrine of pure (divine) persuasive power. Even if we think of Mikael Stenmark himself as a process or as a closely integrated set of processes, this in no way implies that he would therefore lack coercive power. The megaprocess called Stenmark could still, through other processes such as moving his hands and grasping and holding the young girl with the headphones, stop her from crossing the street, or equally he could cut down trees and build a house.

Even if this is so, it could still be the case that the doctrine of process theism is a core claim of panentheism. The doctrine that a panentheist then would accept is:

(14) God, just like everything else that exists, is, or at least is best conceived in terms of, a process.

If everything else should be understood to be process, then I see no obvious reason why we have to make an exception for God. But is it further the case that panentheism lies closer to, or is actually entailed by, process ontology? That such a relationship exists is suggested in the introduction to one book on panentheistic reflections on God's presence in a scientific world, where the first line of argument for panentheism is taken to be metaphysical: if one accept that "subjects are not isolated but exist essentially in relation. This would mean that God could not be understood as separate from the world but only as existing in interdependent relationship to it." 20

This is an unconvincing argument, since things or processes could be ontologically distinct but might still not be isolated and could still have interdependent relationships. The processes of my wife and I are two ontologically distinct megaprocesses, and although we are the main reason why our children exist, they, or these particular megaprocesses, are ontologically distinct from us and from each other. There are interdependent relationships between the four of us, but ontologically speaking the existence of Jacob and Beatrice would not be threatened by the death

\footnotetext{
19 Nicholas Rescher, "The Promise of Process Philosophy," ed. Constantin V. Boundas, Columbia Companion to Twentieth-Century Philosophies, New York: Columbia University Press, 2007, 151.

20 "Summaries of the Contributions to this Volume," eds. Philip Clayton and Arthur Peacocke, In Whom We Live and Move and Have Our Being, Grand Rapids, Mich.: Eerdmans, 2004, xii.
} 
of their mother and father. Traditional theists could in a similar fashion argue that even if God is a megaprocess, God is still (ontologically) distinct from the world and in no way depends on the world for God's own existence. One could consistently embrace both the doctrine of process theism and the doctrine of ontological distinction. Rescher seems to be a process theist who holds, or is very close to holding, such a view, as he writes:

God does not constitute part of the world's matrix of physical processes but nevertheless, in some fashion or other, participates in it. ... But what matters first and foremost from the angle of process theology is the fact that God and his world are processually interconnected; the issue the manner how is something secondary that can be left open for further reflection. So conceived, God is not exactly of the world of physical reality, but does indeed participate in it processually - everywhere touching, affecting, and informing its operations. ... To reemphasize: process theology envisions a God who, though not of the world, is nevertheless present in it in a way that renders him, too, subject to the temporality that pervades its domain. ${ }^{21}$

It is possible to read this as an expression of the doctrine of conservation as it might be fleshed out by a traditional theist who is an open theist and embraces a process ontology and the doctrine of process theism. Whether or not this is a correct understanding of Rescher's conception of God, it is possible to be a traditional theist and maintain that God is, or is best understood, in terms of a process. Already assuming the truth of minimal personal theism (MPT), the idea is then that there exists not a substance or individual but a personal process that is such that it does not depend on any other processes for its existence (the doctrine of asymmetrical dependence), but all other processes depend both for their existence (the doctrine of creation) and continuity (the doctrine of conservation) on this process; and that process we call God.

Still, traditional theists are typically traditional metaphysicians. Joshua Hoffman and Gary S. Rosenkrantz also offer a reason why this, contrary to what I have just suggested, must be so. They maintain:

God is a maximally great substance, rather than a maximally great time, place, event, boundary, collection, number, property, relation or proposition. ... It might be objected that a person [also a personal God] need not be a substance, but could be a temporally extended event or process. Our reply is as follows. Necessarily, an event or process occurs; and necessarily, a substance exists but does not occur. Although it is coherent to say that a person exists, for instance, that Socrates exists, it is absurd to say that a person occurs, for instance that Socrates occurs. We conclude that it is a category mistake to identify a person with a temporally extended event or process. $^{22}$

\footnotetext{
21 Nicholas Rescher, "Process Theology_God in and for Nature," ed. Chad Meister, The Philosophy of Religion Reader, London: Routledge, 2008, 162 and 165.

22 Joshua Hoffman and Gary S. Rosenkrantz, The Divine Attributes, Oxford: Blackwell, 2002, 14 and 18.
} 
I think — although a more detailed discussion is required - that panentheists or traditional theists who accept process ontology and the doctrine of process theism could respond that this would be a proper objection if God were supposed to be a process in analogy with the Vietnam War or globalization, that is, a subjectless process. To see God as such a process would be a category mistake, but God is a personal (or person-like) megaprocess, just like Socrates, and therefore we need only to change our linguistic expressions to adjust for this change in ontology.

To conclude, it is neither the case that panentheists must accept nor that traditional theists must reject the doctrine of process theism. Even though the doctrine or claim (14), that God, just like everything else that exists, is, or at least is best conceived of, in terms of a process, is taken by many panentheists to be a core claim, it is actually an extension claim. It is, furthermore and perhaps surprisingly to some, a possible extension claim of traditional theism as well. Moreover, the doctrine of process theism does not seem to offer any support for the doctrine of pure divine persuasive power.

\section{Panpsychism}

A central part of the conception of God and the God-world relation which process theists embrace is not merely process ontology but also panpsychism (or panexperimentalism). Again, this is Whitehead's philosophy having an impact on panentheists who are process metaphysicians. In Whitehead's metaphysics, every entity has a physical and mental pole, but these entities are not necessarily real beings or enduring individuals themselves. So, human consciousness is far from being the only form of mentality in the world, even if it is a higher form than any other on earth. One core idea is, in the words of David Ray Griffin, "that all fully actual entities have at least some iota of spontaneity (self-determination) and experience." 23 The other is that God is no exception. In God, the physical and mental poles are called the "consequent nature" and the "primordial nature" respectively. As with the physical and mental poles of natural things, so the two aspects are distinguishable but inseparable parts of God.

Whitehead is of course not the only philosopher who has developed a panpsychistic ontology, so, as was our approach with process ontology, we must again allow a variety of views when it comes to panpsychism. Its adherents all believe, however, that there is much more consciousness or some kind of experience, no matter how basic, in the world than most Westerners and indeed contemporary metaphysicians tend to think there is. It is attractive to some philosophers because it offers a middle way between physicalism and dualism. ${ }^{24}$

\footnotetext{
${ }^{23}$ David Ray Griffin, "Process Theology and the Christian Good News: A Response to Classical Free Will Theism," eds. John B Cobb Jr. and Clark H. Pinnock, Searching for an Adequate God, Grand Rapids, Mich.: Eerdmans, 2000, 4.

${ }^{24}$ Oliver Li, Panentheism, Panpsychism and Neuroscience, Uppsala Studies in Philosophy of Religion 4, Uppsala University, 2018, 85f.
} 
Why panpsychism is important for our discussion is not that it gives us a "doctrine of panpsychistic theism," since in panentheism we already have that element in the doctrine of ontological divine inclusion: the world is a part of (a personal) God but not identical with God. God, in a similar (but not identical) way to ourselves, has a body and a mind. Panpsychism is of relevance rather because it could be the case that process panentheists need panpsychism in their attempt to justify the doctrine of pure divine persuasive power.

First of all the doctrine is stated within a panpsychistic framework. The idea is that God could lure, or exercise divine persuasive power on, all things, because they have both physical and mental poles. The exercise of persuasive power does not require that the object of persuasion is an agent or a sentient being, but merely that things have some iota of spontaneity (self-determination) and experience. Things differ in their awareness of and openness to divine persuasion, but no one cangiven the truth of panpsychism - avoid such persuasion entirely. Secondly, because all things always possess some power of self-determination (analogous to our free will), God lacks the power to unilaterally bring about any specific state of affairs, and thus all reality is always co-created. Griffin writes that:

divine influence never cancels out a creature's power of self-determination or its power to exert causal influence on other creatures. No event in the world, accordingly, is ever brought about unilaterally by God; divine-creaturely cooperation is always involved. This fact reflects the very nature of the divine-world relation, not simply a voluntary self-limitation [as in open theism]. ${ }^{25}$

So, God's lack of coercive powers is not due to self-limitation, but to the panpsychic character of the world that God has created and which constitutes a part of the divine nature itself. Furthermore it is taken, I assume, not to be within God's power to create another kind of world, that is, a non-panpsychic one, at least not if God intended there to be enduring individuals with similar capacities to our human ones, and for them to evolve in their own world.

It follows that those panentheists who embrace the doctrine of pure persuasive power must, it seems, also accept panpsychism. The exercise of persuasive power which paradigmatically applies to humans or agents and which can plausible be extended to all sentient beings, only makes sense if the rest of the things in creation have both physical and mental poles, that is, as mentioned previously, if there is much more consciousness, or some kind of experience no matter how basic, in the world than most Westerners, and indeed contemporary metaphysicians generally, tend to think there is. Panpsychism makes possible divine exercise of persuasive power on all created things and processes in the world. The fact that we cannot convince the rocks, weeds and snails in the grass in our garden to go somewhere else is due to our limited persuasive powers and not-as I assume we naturally thinkthat they are not proper objects of that kind of power, and when we want to get rid of them, we exercise our coercive powers.

Now, even if the doctrine of pure persuasive power only makes sense if panpsychism is true, I fail to see why that would make coercive power impossible to

${ }^{25}$ Griffin, "Process Theology and the Christian Good News," 2000, 13. 
exercise in a panpsychic world. I am not going to develop an argument for this, but simply point out that contemporary panpsychists within philosophy in general do not seem to acknowledge that panpsychism and the exercise of coercive powers cannot be compatible. Moreover, since we can, it appears, use coercive powers not merely on physical things like rocks and trees, but also on animals and other humans (things we all agree have a mental pole) it is hard to see that panpsychism per se can warrant a rejection of coercive power's existence. It is still possible of course that there is something in God's nature that makes it impossible for God, but not for humans and other animals, to exercise coercive power, but neither process ontology nor panpsychism gives us grounds for thinking so.

\section{Concluding remarks}

The somewhat surprising result of my analysis is that many of those things which in the panentheistic debate are simply taken for granted as distinguishing panentheism from traditional theism, or vice versa, turn out to be possible extension claims, rather than core doctrines of these different conceptions of God. I have nevertheless suggested that it is possible to draw a line differentiating between them. The essential difference is that traditional theists think that God is (ontologically) distinct from the world and does not depend on it for God's own existence, whereas panentheists believe that God (ontologically) includes the world and depends on the world for God's own existence. Both, in contrast to deists, stress the active presence of God in the world, but in different ways. The greatest challenge many panentheists face is to give a convincing argument as to why we should think that God's power can never be coercive, but must always be persuasive. It rather seems (although I have not had the space to develop this idea) that the doctrine of pure divine persuasive power is an ad hoc hypothesis composed in order to offer a convenient way out of the problem of evil. The good news is that there is nothing in panentheism that requires that we accept this doctrine.

Open Access This article is distributed under the terms of the Creative Commons Attribution 4.0 International License (http://creativecommons.org/licenses/by/4.0/), which permits unrestricted use, distribution, and reproduction in any medium, provided you give appropriate credit to the original author(s) and the source, provide a link to the Creative Commons license, and indicate if changes were made. 